\title{
GEOLOGY
}

UDC 553.061.121.17: 553.81

\author{
M. V. Ruzina, Dr. Sc. (Geol.), Prof., \\ orcid.org/0000-0002-6612-9750, \\ O. A. Tereshkova, Cand. Sc. (Geol.), Assoc. Prof., \\ orcid.org/0000-0001-5731-7349, \\ N.V. Bilan, Cand. Sc. (Geol.), Assoc. Prof., \\ orcid.org/0000-0002-4086-7827, \\ I. V.Zhyltsova, Cand. Sc. (Geol.), Assoc. Prof., \\ orcid.org/0000-0002-9383-4797
}

DOI: $10.29202 /$ nvngu/2018-6/2

National Mining University, Dnipro, Ukraine, e-mail: ruzinamari@gmail.com

\section{NON-KIMBERLITIC SOURCES OF DIAMONDS AND PROSPECTS OF THEIR DISCOVERY IN THE UKRAINIAN SHIELD}

Purpose. To substantiate the prospects of potentially diamondiferous formations of non-kimberlite genesis and improve the forecasting criteria for diamond deposits within the Ukrainian Shield.

Methodology. The research involved a complex study of the structural features, compositional-indicating evidence and distribution regularities of potentially diamond-bearing formations of non-kimberlite genesis. Petrographic characteristics and composition of ore mineralization were studied in thin and polished sections using a polarization microscope Altami POLAR P-312. To substantiate the material composition of diamond-prospecting rocks, the results of X-ray, thermal and microprobe analyzes were interpreted.

Findings. Fluid-explosive units that have been discovered within the Inhul megablock of the Ukrainian Shield are diamondiferous formations. Fluid-explosive units from the Bilozerska greenstone structure within the Middle Prydniprovie megablock of the Ukrainian shield is largely similar to the above-mentioned unites as well as the diamondbearing phyllites from Diamantina (Brazil) and diamond-bearing visherites of the Urals. This by analogy with a number of world metallogenic provinces allows predicting the possibility of discovery of non-traditional diamondprospective formations of non-kimberlite genesis within the Middle Prydniprovie megablock of the Ukrainian Shield as it is a typical Archean craton.

Originality. Established factual background is indicative of credible occurrences of potentially diamond-bearing formations of non-kimberlite genesis within the Middle Prydniprovie megablock. During diagnostics of fluid-explosive units of the studied region, a number of structural features observed exclusively in fluidolites are identified. Fluidexplosive formations also contain abnormal concentrations of noble metals.

Practical value. The results of the research allow us to forecast the possible discovery of non-traditional diamondprospective formations of non-kimberlite genesis within the Middle Prydniprovie megablock of the Ukrainian Shield.

Keywords: ore formations, fluid-explosive units, pyroclastic kimberlites, metaconglomerate-breccia, diamonds, genesis

Introduction. According to current ideas, there are four basic geologic-genetic types of primary diamond deposits known in the world today [1].

1. Primary diamond deposits associated with kimberlite pipes or diatremes.

According to the content of detrital material, there are massive kimberlites, brecciform kimberlites, kimberlite breccias and tuffs. The mineral composition of kimberlites is characterized by the presence of phenocrysts of olivine, phlogopite, and a binder mass filled with small grains of altered olivine, pyroxene, phlogopite, perovskite, magnetite, monticellite, apatite, and serpentinized and carbonatized glassy bed rock as well.

(c) Ruzina M.V., Tereshkova O.A., Bilan N. V., Zhyltsova I. V., 2018
In such a case, pyroxene in kimberlites forms only microlites in the bulk and does not occur in the form of phenocrysts.

2. In the middle 1970s, diatremes filled with diamondiferous rock - lamproite, rich in potassium and magnesium mafic or ultramafic alkaline volcanic or intrusive hypabyssal rock, were discovered in Australia. Typomorphic minerals of lamproites are represented by the following varieties: magnesian olivine; clinopyroxene (poor in aluminum (less than $1 \mathrm{wt} \% \mathrm{Al}_{2} \mathrm{O}_{3}$ ) and sodium (less than $1 \mathrm{wt} \% \mathrm{Na}_{2} \mathrm{O}$ ) diopside); phlogopite (titaniferous $\left(2-10 \mathrm{wt} \% \mathrm{TiO}_{2}\right.$ ) and aluminum-deficient (5-12 wt\% $\left.\mathrm{Al}_{2} \mathrm{O}_{3}\right)$ ); iron-rich leucite (1-4 wt $\% \mathrm{Fe}_{2} \mathrm{O}_{3}$ ); amphibole (titaniferous $\left(3-5 \mathrm{wt} \% \mathrm{TiO}_{2}\right.$ ) potassium richterite); orthopyroxene; iron-rich sanidine (1-5 wt $\%$ 
$\mathrm{Fe}_{2} \mathrm{O}_{3}$ ); glass, as well as specific minerals vadeite and priderite. However, the simultaneous presence of all the above mentioned minerals is not necessary in lamproites. Accessory minerals are represented by apatite, ilmenite, chromite, Cr-magnetite, nepheline, spinel, perovskite, and titanates - priderite, jeppeite, armcolcolite; $\mathrm{Zr}-\mathrm{Ti}$-silicates.

About $90 \%$ of the diamond reserves of primary sources are concentrated in kimberlite pipes, and about $10 \%$ - in lamproite pipes. The bodies of lamproites are found in the form of stocks, sills, and dikes, which are easily ruined and weathered. Lamproite bodies, in comparison with kimberlite ones, are large-sized and have high concentration of titanium, potassium, phosphorus and some other elements. Lamproites in inclusions contain melts of later differentiates which do not occur in kimberlites. Such high-pressure minerals as pyrope and picroilmenite are not typical for lamproites, which distinguishes them from kimberlites as well.

3. In the late 1960s, V.L. Masaytis, et al. revealed a new genetic type of the primary diamond deposits associated with impactites - rocks formed as a result of impact of space bodies on the Earth surface. The formation of diamonds in them is due to the solid-phase transition of graphite to diamond under shock pressures that occur during the impact process. Such diamonds belong to technical grades.

4. In the middle 1960s of the past century, A. A. Zayachkovskiy and Yu.A. Polkanov, et al. discovered another new genetic type of the primary diamond deposits confined to the crystalline rocks of the metamorphic complex, localized in the Kokchetav Massif of Kazakhstan. Currently, this is the only primary deposit of this genetic type of diamonds in the world. Grain size of diamonds rarely exceeds tenths of a millimeter and forms crystals of cubic habit, skeleton crystal forms and their clots.

At present, the problem of non-kimberlite sources of diamond is in the focus of attention of researchers of diamond-prospective rocks. It is on grounds of the discovery of diamond placers with unknown sources of diamonds and entire new types of diamond-bearing rocks. These placers were found in different parts of the globe and in different geological and structural settings. Diamonds from placers differ in their properties from diamonds from kimberlites.

Analysis of the recent research and publications. The first finds of diamond in the rocks of the ultramafic alkaline carbonatite formation were described in 1986 [1]. In the carbonatites of some regions (Novopoltavka, Ukrainian Shield, Pogranichny area, North Transbaikalia, and others), the presence of native carbon in the form of graphite was also established. It allowed us to suggest the possibility of diamond formation under certain conditions in carbonatites.

The first description of carbonatites containing diamond belongs to F. K. Divaev, who discovered diamondiferous carbonatite dikes in the Chagatai carbonatite-trachyte complex in the region of the South Nuratau ridge on the Tien Shan. Later, these occurrences were characterized by A. V. Lapin, A. A. Frolov, and others [1]. Afterwards, diamonds were found in the carbonatites of Fuerteventura Island, which is part of the Canary archipelago [1].

The composition of the rocks under consideration is characterized by an almost complete absence of deepseated minerals of diamond paragenesis and an exceptional rarity of the persistent rare-metal minerals of carbonatites. A characteristic feature of the rock-forming minerals of these rocks is the increased iron content of silicates - garnet, melilite, mica and pyroxene. Abnormal PT-conditions and the effect of disoxidated fluids cause the mobilization of carbonatite-like units, where diamond crystallization is likely to occur.

A special type of diamondiferous rocks, differing from kimberlites and lamproites, is metamorphosed volcaniclastic komatiites. They were discovered in the area of Dachine of French Guiana. Diamond-bearing komatiites are confined to the Proterozoic island-arc complex, ages $2.11 \pm 0.09 \mathrm{Ga}$. Diamond-bearing ultramafic rocks are spatially confined to a volcanic bench. In most areas they are transformed into thin-bedded albite-carbonate-chlorite-talc schists, but in some outcrops the primary pyroclastic or hyaloclastic volcanic structure is well preserved. The content of diamonds in komatiites is from 1 to 77 crystals per $1 \mathrm{~kg}$ of rock, microdiamonds prevail, but crystals larger than $1 \mathrm{~mm}$ are also found. The size of the largest diamond is $4.6 \mathrm{~mm}$. The morphology of diamond crystals, in particular the presence of cuboctahedra and low isotopic ratios of carbon in diamond ranging from -23 to $-27 \%, \delta^{13} \mathrm{C}$, approve the eclogite source. Among the garnets, minerals of lherzolite paragenesis predominate, and garnets of harzburgite and eclogite parageneses are also present. Minerals, persistent for kimberlites - picroilmenite, chrome diopside and perovskite - have not been established. Researchers of diamondiferous komatiites assume the xenogeneic origin of the diamond in these rocks [1].

In the northwestern Gabon several ultramafic dikes have been established. They were classified as diamondiferous meta-kimberlites on the basis of the presence of chromium spinel and diamond, common in kimberlites, and also the characteristic spectrum of rare-earth elements. Other indicator minerals of kimberlites - pyrope garnet, picroilmenite and chrome-diopside - are exceedingly rare or absent [1].

The group of metamorphosed ancient kimberlites or lamproites probably includes diamondiferous phyllites of Brazil, which are located in the Diamantina area. They form dikes, veins, and less often flattened chimney bodies with numerous apophyses. Diamond-bearing phyllites are outwardly similar to phyllites. Diamondbearing phyllites are with a greasy feel, schistose, white, ashy, pink, sometimes red rocks. The rocks are more often massive, but sometimes they have the form of breccias containing a large number of fragments of the enclosing rocks of the Itakolumi series. Dykes are intersected by quartz veins oriented perpendicularly or parallel to the selvages and crossed fragments of the enclosed rocks. Massive phyllites of dikes are characterized by a substantially sericite composition, sometimes with a 
slight infusion of chlorite. In the sericite mass, traces of the fluid texture and relicts of phenocrysts, completely replaced by sericite and bordered with a hematite rim, are visible under the microscope. The bulk contains segregations of martitized magnetite, as well as cubic and octahedral aggregates of rutile and anatase.

According to the majority of researchers of diamondiferous problems, phyllites are altered kimberlites. Diamonds are found in most dikes of phyllites, in many of them - in industrial concentrations. These dikes act as one of the main sources of diamond placers of a younger age (from Late Proterozoic to present-day).

Among non-kimberlite sources of diamond there are currently established volcaniclastic kimberlites accumulated in marine sediments of the Fort à la Corne area in central Saskatchewan, Canada.

In this area, P. Nixon and K. Leahy [1] revealed extracraterial volcaniclastic deposits represented by two varieties - pyroclastic kimberlites (PK) and processed pyroclastic kimberlites (PPK). The petrographic composition of pyroclastic kimberlites is characterized by the presence of angular and euhedral grains of serpentinized olivine, kimberlite lapilli, mantle and crustal xenoliths, and alteration products - xenocrystals including diamonds, evenly distributed in the mass of serpentinized olivine. Pyroclastic kimberlites are divided into roughly sorted, slightly layered, and less often into massive ones. The transition from the PK to PPK is traced through massive, sorted and layered pyroclastic sands. PPK is characterized by lamination with easy grade and alternation of aleuritic and coarse-grained interlayers. Along with this, rocks contain up to $90 \%$ of tufogenic clastic material.

The processed pyroclastic kimberlites of the Fort à la Corne area contain diverse tuffaceous clastics. According to [1], pyroclastic kimberlites and processed pyroclastic kimberlites are most likely derived from several volcanic structures located hundreds of meters from the described volcaniclastic sediments.

In the distribution area of volcaniclastic kimberlites in Fort à la Corne, a large number of craters of Cretaceous age have been revealed. According to the authors [1], these pyroclastic kimberlites are distal ash products of volcanoes accumulating in shallow basins not too far from the source. According to N. N. Zinchuk (monograph "Postmagmatic minerals of kimberlites", 2000), the parageneses of secondary minerals in kimberlites, represented by the serpentine + saponite + vermiculite association (as a result of the phlogopite transformation), indicates an insignificant level of erosional truncation of kimberlite bodies. It is widely accepted that the tuffaceous units are confined to the upper horizons of the pipes, the breccias to the middle ones, and the massive kimberlites to the lower horizons of the kimberlite pipes.

Such a global presence of findings of diamond crystals and discoveries of deposits of non-kimberlite type testifies to the growth of metastable crystals. According to the experimental data [2], the thermodynamic growth conditions of single crystals on a diamond substrate do not exceed a temperature of $1100 \mathrm{~K}$ and correspond to pressures of the range 105...108 Pa. Authors in [3] used polycrystalline nuclei in the experiments on growing of diamond single crystals. These crystals were synthesized using various methods, including shock wave ones with high-energy explosive composites initiated by laser pulsed radiation [3].

With regard to the genesis of volcaniclastic kimberlites, it is commonly supposed that pyroclastic kimberlites in marine sediments are a special type of diamondiferous units, the genesis of which is at the intersection of the primary kimberlites and redeposited placers.

Objectives of the article. In recent decades, the problem of diamond minerageny has started to develop very dynamically due to a number of unexpected discoveries. In addition to such complexes as carbonatites of orogenic zones, dikes and pipes of alkaline ultramafic rocks and mafic lamprophyres, komatiites and phyllite-like rocks, fluid-explosive formations are also a new source of diamond content.

The detection of fluid-explosive units within certain territories of some regions allows estimating their prospects for various types of minerals [4], including diamonds. In the late 1990s, such diamonds were first discovered as "industrial primary diamond deposits of fluid type" by V. V. Ostroumov, A. Ya. Rybalchenko, A. P. Kazak and others in the Perm region in the north of the Urals [5].

Similar diamond-prospective rocks were studied with the participation of the authors of the article within the Middle Prydniprovie and Inhul megablocks of the Ukrainian Shield.

The purpose of the work is to substantiate the prospects of potentially diamondiferous formations of nonkimberlite genesis and to improve the criteria for forecasting diamond deposits within the Ukrainian Shield.

Methods. The research method involved a complex study of the structural features, compositional-indicating evidences and distribution regularities of potentially diamond-bearing formations of non-kimberlite genesis.

Presentation of the main research and explanation of scientific results. Fluid-explosive units formed as a result of chemical and physicomechanical interaction of deep fluids with surface and near-surface rocks have also been subject to research in recent decades due to their potential diamond content, as well as high prospects for the occurrences of gold and rare metals.

Fluidolites are rocks formed as a result of the action of high-temperature fluids on sedimentary complexes (Fig. 1) and forming complex combinations with them fluid systems [6].

In the basement and sedimentary cover of the Ukrainian Shield, there are occurrences of diamonds that originated at the activation stages in the Precambrian and the Phanerozoic, which are associated with the formation complexes of the basement, their crusts of weathering and later sedimentary collectors.

During diamond prospecting in the northeastern part of the Inhul megablock within the Ukrainian Shield (1994-2005), a number of explosive structures with established signs of diamond-bearing xenotuff-breccia in the Lesnoy, Gruzska, Severny Ositnyazhsky and Ositnyazhsky areas were discovered by the specialists of State Enterprise "Kirovgeologiya" [7]. 
As a result of studying diamondiferous formations of different genetic types within the Ukrainian Shield, G. M. Yatsenko, et al. [8] substantiated the significant role of fluid-explosive processes in the formation of diamonds and many other useful components.

According to [9] explosive processes and their effects within the Eastern European platform do not correspond to magmatic processes, but secondary metasomatic and hydrothermal processes can be identical.

One of the prospective for diamond-bearing objects is the Middle Prydniprovie megablock, a craton of the Archean age.

The Bilozerska greenstone structure (BGSS) is one of the largest within the Middle Prydniprovie megablock of the Ukrainian Shield: its width reaches $20 \mathrm{~km}$, and its extent in the meridian direction is $60 \mathrm{~km}$.

Within the metaconglomerate-breccia of the pereverzivska suite of the Bilozerska series, the elements of fluidolites' structures in the composition of metaconglomerate-breccia were detected. These rocks are abundant in a north-south strip with a width of up to $5 \mathrm{~km}$. The length of the north-south strip at issue is about 9-11 km. In this part of the cross section, among the clastogenic rocks, as many as seven units of conglomerate-breccias, interbedded with meta-sandstones and schists, are revealed. The observed thickness of the packs is in the range from $80-100$ to $200-250 \mathrm{~m}$. The behavior of the packs and certain layers along the strike has not been studied. They have interrupted lenticular character. The packs of conglomerate-containing layers tend to wedge out in the north.

Metaconglomerate-breccias are rocks of coarsegrained texture, consisting of fragments of rocks, cemented with sand cement. They are very heterogeneous in composition, quantity, size and shape of debris, among which in order of prevalence prevail: quartzites, vein quartz, ferruginous quartzites (carbonate, silicate, magnetite-carbonate, and magnetite), schists (quartzchlorite, less often quartz-sericite). Fewer fragments of several varieties of mainly felsic effusive rocks and rarely rich iron ores are registered.

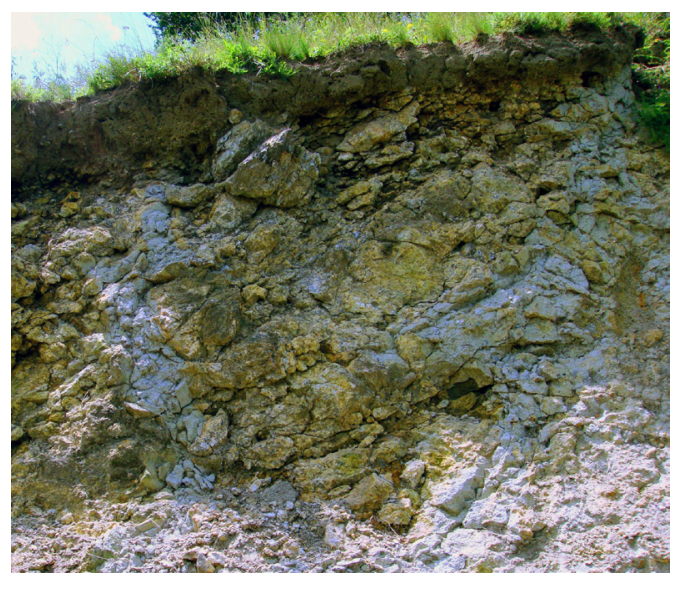

$a$
The shape of coexisting fragments is different: angular, angular-rounded, rounded, and often flattened oriented along the bedding. The size of the fragments varies from $3-5$ to $100-150 \mathrm{~mm}$. The ratio between the volume of debris and cement is not constant. For the described meta-psephites, a very poor sorting of clastic fraction is characteristic for all indices: composition, shape, size and quantity. Cement of psephite fragments is represented by meta-sandstones.

The composition of the psammite fraction of the metaconglomerate-breccias is richer than that of the psephitic fragments. Particles of effusive rocks (albitophyres) and clusters of quartz with plagioclase occur more frequently. There is an impurity of gravel material with the size of certain debris up to $2.5-10 \mathrm{~mm}$ in polymictic meta-sandstones. Quantitatively, quartz grains predominate in cement of psephites. The fragments of veined quartz are distinguished by the most perfect rounded shape and large size of the particles. Around them, there are rims of overgrowth (regeneration) from quartz and sericite.

There are aggregates of quartz grains, vein quartz (often combed quartz), mafic rocks, relicts of felsic volcanites, and occasionally fragments of carbonate and tourmaline rocks in poorly-rounded and angular fragments. There is a significant amount of impurities of pyroclastic material, both in the composition of clastic fraction and in cement, in almost all thin sections. Pyroclasts are present in the form of sharply angular (often triangular) and acicular fragments, certain grains have fused edges. Secondary sulphidization and the development of aggregates of metasomatic chloritoid presented in cement as well as "penetrating" clastic grains are characteristic for all the examined thin sections from metaconglomerate-breccias. Grains of chloritoid are assembled in cross-shaped and sheaf-shaped, sometimes - up to "sun-shaped" aggregates. Moreover, parallel veins of pyrite, quartz, crosscutting debris and cement are characteristic too.

In some thin sections, elements of fluidolites' structures were first established (Fig. 2), which suggests that there is a fluid-explosive formation similar to that described for a number of diamond prospective objects



Fig. 1. Fluid-explosive units with feeders in sedimentary rocks:

$a$ - outcrop of Paleocene sediments $(2 \times 3 \mathrm{~m}$, riverbed of Sukhyi Tashlyk) of the Inhul megablock within the Ukrainian shield; $b$ - Devonian outcrop on the bank of the river Rossolnaya, Northern Urals [6] 
[6]. Structural features and petrographic composition of the metaconglomerate-breccias of the Pereverzivska suite are in many respects similar to the above mentioned units, which makes it possible to predict fairly high metallogenic prospects of the territory with respect to diamonds of non-kimberlite genesis.

Researchers of Dnipro Polytechnic (former National Mining University) including the authors earlier revealed comprehensive mineralization and single ore occurrences of noble metals in hydrothermal metasomatites of listvenite-beresites, greisen and carbonaceous formations within the Mikhailovska suite of the Bilozerska series and in the conglomerate-breccia of the Pereverzivska suite of the Bilozerska greenstone structure [10]. Carbonaceous phyllonites (carbonate-sericite-graphite composition) show an analogy with diamondiferous phyllites of the Diamantina region (Brazil). Fragments of the quartztourmaline rock, similar in composition to the diamondcontaining itacolumite of the Diamantina region (Brazil), were also found in the fragments of the metaconglomerate-breccias of the Pereverzivska suite.

Earlier, with the participation of the authors, as a result of study of the Inhul megablock of the Ukrainian shield, fluid-explosive units similar in composition to diamondbearing mica-type lamprophyres of the minette type from Parker Lake, Canada, as well as to the diamond-bearing rivnenskites from the Novoukrainsky massif of the Inhul megablock of the Ukrainian Shield, were revealed. It allowed us to assume their prospects for diamond [11].

The textural and structural features of fluidolites are distinguished by a considerable variety, which is due to differences in the composition of fluids and rocks through which they pass. In the diagnostics of fluid-explosive formations, a number of structural features have been identified, observed exclusively in fluidolites [6]:

1. The characteristic structure of the fluidolites' matrix, manifested in the disintegration of grains and large xenoliths, the presence of split, "dragged" by fluid flows of psammite grains in combination with perfectly rounded grains. Newly formed minerals - regenerated quartz and plagioclase - are formed simultaneously with the disintegration of grains. The microstructures of the fluidolite matrix of the Inhul megablock are shown in Fig. 3, $a$.

2. The presence of microspheres, consisting of quartz, feldspar, ore substance and volcanic glass (Figs. 3, $b-c$ ).

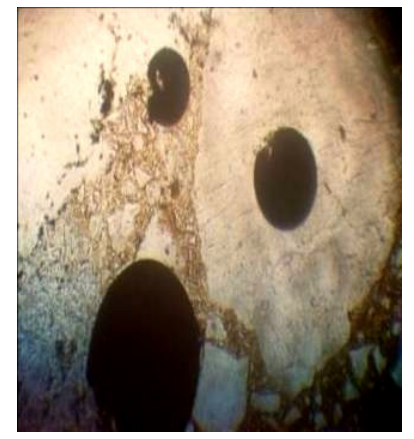

$a$

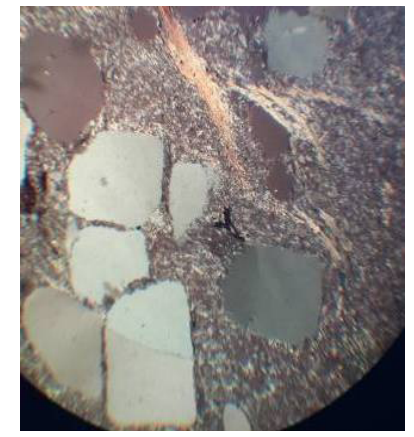

$b$

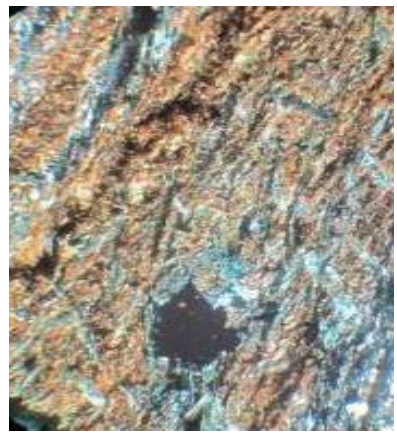

$c$

Fig. 2. Elements of structures of fluidolites (thin sections):

$a$ - pyrite spheroids in metaconglomerate-breccias of the Pereverzivska suite, transmitted light, plan polarized light, 90x zoom; $b$ - the structure "in situ" (xenoliths "exploded" in place) in quartz grains and elements of the fluid structure in sericite aggregates; $c-$ a grid of newly formed chloritoid (stress-mineral), cross polarized light, $90 x$ zoom

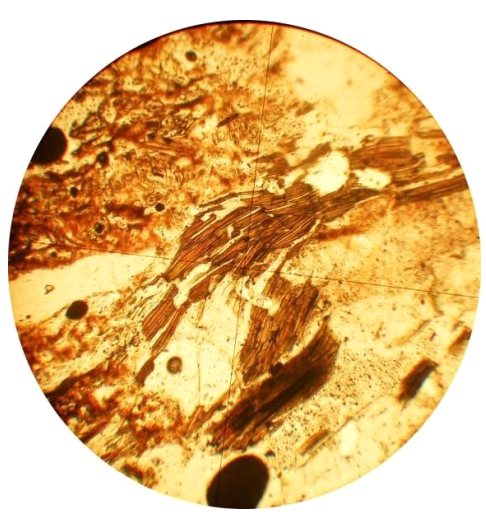

$a$



$b$

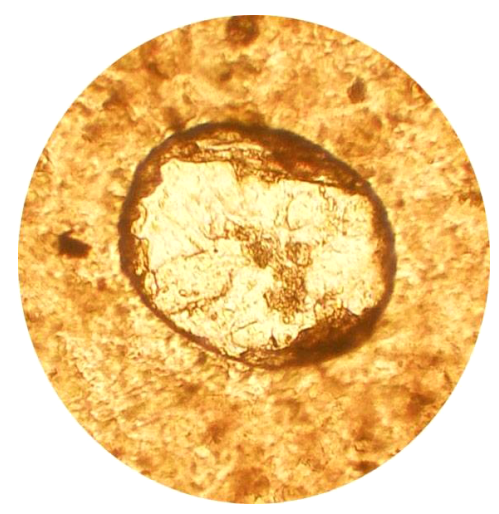

$c$

Fig. 3. Typical structures of the fluidolite matrix of the Inhul megablock of the Ukrainian shield in the thin sections:

$a$ - split into fragments, curved grains of newly formed biotite, oriented along the direction of the "fluid" microstructure; $b-$ globular forms of ore mineral extraction in the fluidolite from the outcrop in the vil. Lebedivka. Plan polarized light, 110x zoom; $c$ - oval grains of volcanic glass, pushing aside the iron compound from the fluidolite, outcrop in the vil. Lebedivka. Plan polarized light, 140x zoom 


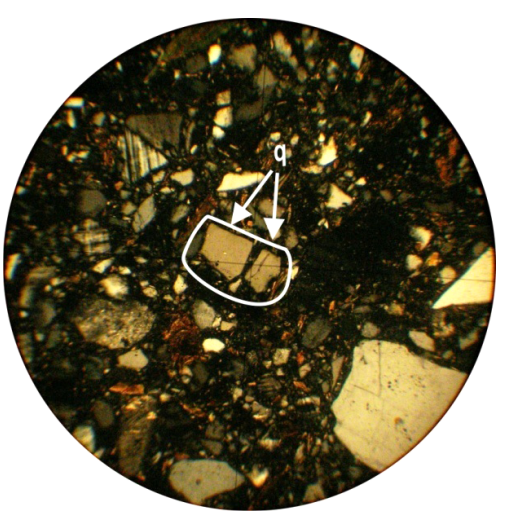

$a$

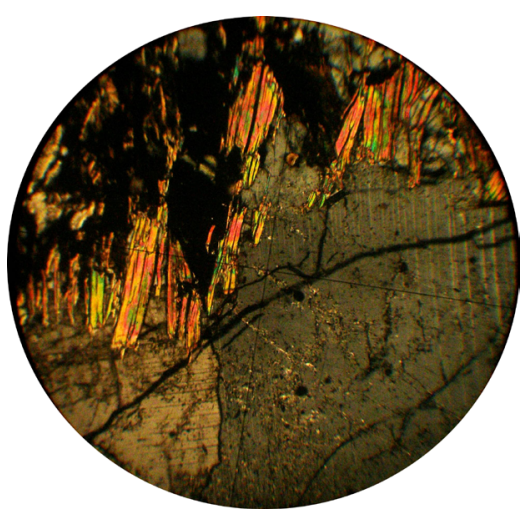

$b$

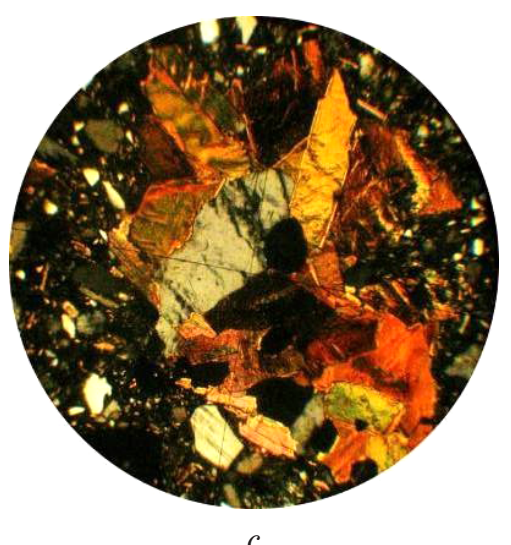

$c$

Fig. 4. Disintegrated "in situ” grain of quartz (in the center) in fluidolite (a). "Ladder-type" arrangement of split biotite grains intergrowing through grains of quartz and plagioclase (b). "Vortex" overgrowing of plagioclase grains by newly formed biotite in the fluidolite (in the form of "snowball" structures) (c). Photo of thin section. Cross polarized light, $105 x$ zoom

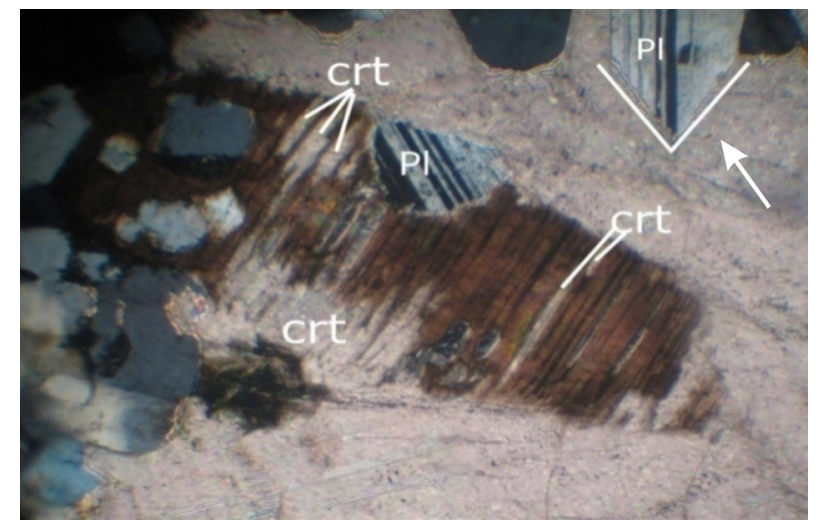

Fig. 5. Carbonate (crt), penetrating the biotite grains and "spear-like" plagioclase ( $\mathrm{Pl}$, shown by an arrow), penetrating the aggregate of carbonate. Photo of the thin section. Cross polarized light, 90x zoom

M.N.Afanasov described these structural features when viewing washings of fluidized rock where quartz microspherules up to $0.7 \mathrm{~mm}$ in size were found. Perfectly round sections of microcline grains are observed more rarely in the thin sections. Microspheres in the finepsammite fraction of fluidolites are found among splintered grains, sometimes in the form of agglomerates. A number of scientists suggest that their ideal spherical shape is the result of the process of coalescence - the formation of globules in a liquid or viscous silicic fluid flow due to the action of intermolecular attraction.

3. The presence of "exploded xenoliths". The xenoliths split into fragments and grains of fluidolites are called "exploded" or split "directly on the spot", "in situ" (Fig. 4,a), the presence of split biotite grains that intergrow through the grains of quartz and plagioclase (Fig. 4, b), the presence of structures like "snowball". There is turbulent ("vortex") overgrow of plagioclase by newly formed biotite grains in the fluidolites (Fig. 4, c).

4. The presence of newly formed biotite aggregates, penetrating, "piercing" the grains of quartz and plagioclase and aggregates of carbonate, piercing the grains of newly formed minerals (Fig. 5).
Some researchers believe that this indication is one of the most important, distinguishing between tuffisites from psephites and psammites [6]. The decisive indication of the classification of clastic rocks as fluidolites is the fragmentation of rock debris, crystals and glasses presented in breccias directly on the site with the penetration of cement into them. Most clearly, this detail of the microstructure of fluidolites is manifested in grains of quartz. Some crushed quartz grains are broken by a dense fracture network, preserving the overall integrity, and some grains partially break up into fragments, the totality of which reveals a connection with the primary shape of the grain. Similar details of structures are called "exploded in situ" and are not observed in rocks of other genesis [6].

\section{Conclusions.}

1. Fluid-explosive units discovered in the Inhul megablock of the Ukrainian Shield are diamondiferous formations.

2. The fluid-explosive units of the Bilozerska greenstone structure of the Middle Prydniprovie megablock of the Ukrainian Shield are in many respects similar to the above-mentioned units, as well as diamondiferous units of the Diamantina region (Brazil).

3. In a similar way to a number of ore provinces in the world, our results allow us to forecast the possible discovery of non-traditional diamond-prospective formations of non-kimberlite genesis within the Middle Prydniprovie megablock of the Ukrainian Shield.

\section{References.}

1. Belov, S.V., Lapin, A.V., Tolstov, A.V. and Frolov, A.A., 2008. Minerageny of platform magmatism (traps, carbonatites, kimberlites. Novosibirsk: SO RAN. 2. Sobolev, V.V., Taran, Y. N. and Gubenko, S. I., 1997. Shock wave use for diamond synthesis. Journal De Physique IV, 7(3), pp.73-75. DOI: 10.1051/jp4:1997315.

3. Chernaj, A. V., Sobolev, V.V., Ilyushin, M.A., Zhitnik, N.E., 1994. The method of obtaining mechanical loading pulses based on a laser initiation of explosion of explosive coatings. Fizika Goreniya $i$ Vzryva, 30(2), pp. 106-111. Available at: <ttps://www.researchgate. net/publication/292548581_The_method_of_obtain- 
ing_mechanical_loading_pulses_based_on_a_laser_ initiation_of_explosion_of_explosive_coatings $>$ [Accessed 11 July 2017].

4. Afanasov, M.N., Kazak, A.P. and Yakobson, K.E., 2012. Fluidolites and minerals in the north-west of Russia: prospecting and forecast studies based on detailed geological and mineralogical analysis. Saarbrücken: LAP LAMBERT [online]. Available at: <http://fluidolit.ucoz.ru/load/publikacii/111/2-1-0-21> [Accessed 29 October 2017].

5. Rybalchenko, A. Ya., Rybalchenko, T. M. and Silaev, V.I., 2011. Theoretical basis for forecasting and exploration of primary diamonds deposits of tuffizit type. Proceedings of the Komi Science Centre of the Ural Division of the Russian Academy of Sciences [pdf], 1(5), pp. 54-66. Available at: <http://www.izvestia.komisc. ru/Archive/i05_ann.files/rybalchenko.pdf> [Accessed 12 September 2017].

6. Kazak, A. P., Kopylova, N. N., Tolmacheva, E. V. and Yakobson, K. E., 2008. Fluid-explosive units in sedimentary complex. Saint Petersburg: Mineral [online]. Available at: <http://www.evgengusev.narod.ru/fluidolit/ fluidolit.html $>$ [Accessed 3 July 2017].

7. Kalashnyk, H.A., Fedoryshyn, Yu. I., Kuzmin, A. V. and Kiriano, M. M., 2016. Preconditions of formation and criteria for prediction of diamondiferrous structures on the Ukrainian shield. Naukovyi Visnyk Natsionalnoho Hirnychoho Universytetu, 6, pp. 22-40.

8. Yatsenko, G. M., Bekesha, S.N., Hayovskiy, O.V. and Yatsenko, I. G., 2011. Activation periods, ore-bearing structures and formations of lamproite type in the Archean and Proterozoic blocks of the Ukrainian shield. Article 2. Kirovograd block. Mineralni Resursy Ukrainy [e-journal], 2, pp.25-29. Available at: <http://fluidolit. ucoz.ru/publ/publikacii/ehpokhi_aktivizacii_rudonosnye_struktury_i_formacii_lamproitovogo_tipa_v_ arkhejskikh_i_proterozojskikh_blokakh_ukrainskogo_shhita/2-1-0-18> [Accessed 20 January 2018].

9. Yatsenko, G., Bekesha, S., Hayovskyi, O. and Yatsenko, I., 2015. Fluidizate-explosive ore genesis and minerageny of the East European platform margin in Ukraine, Mineralogical Review, 2, pp. 55-61.

10. Ruzina, M. V., Tereshkova, O. A., Yatsyna, D. V. and Dodatko, A.D., 2013. Listvenite-beresites from the Middle Predniprovie megablock of the Ukrainian shield and its ore content. Naukovyi Visnyk Natsionalnoho Hirnychoho Universytetu, 1, pp. 24-32.

11. Ruzina, M.V., Tereshkova, O.A., Bilan, N.V. and Vunda, N.G., 2016. Prospects for diamond content in Raygorodska strata of the Ukrainian shield. Naukovyi Visnyk Natsionalnoho Hirnychoho Universytetu, 1, pp. 11-18.

\section{Некімберлітові джерела алмазоносності та перспективи їх виявлення в межах Українського щита}

\section{М. В. Рузіна, О. А. Терешкова, Н. В. Білан, I. В. Жильиова}

Державний вищий навчальний заклад „Національний гірничий університет“, м. Дніпро, Україна, e-mail: ruzinamari@gmail.com
Мета. Обгрунтування перспектив потенційно алмазоносних формацій некімберлітового генезису та вдосконалення критеріїв прогнозування родовищ алмазу в межах Українського щита.

Методика. Комплексне вивчення особливостей будови, речовинно-індикаційних ознак і закономірностей розподілу потенційно алмазоносних формацій некімберлітового генезису. Під час вивчення петрографічних особливостей і складу рудної мінералізації проводилося вивчення шліфів і аншліфів 3 використанням рудно-поляризаційного мікроскопа Альтами ПОЛАР Р-312. Для обгрунтування речовинного складу алмазоперспективних порід проведена інтерпретація результатів рентгеноструктурного, термічного й мікрозондового аналізів.

Результати. Флюїдно-експлозивні утворення, що виявлені в межах Інгульського мегаблоку Українського щита $€$ алмазоносними формаціями. Флюїдно-експлозивні утворення Білозерської зеленокам'яної структури Середньопридніпровського мегаблоку Українського щита за багатьма ознаками аналогічні утворенням району Діамантина (Бразилія) та алмазоносним вішеритам Уралу. Це, за аналогією з низкою рудних провінцій світу, дозволяє прогнозувати можливість відкриття нетрадиційних алмазоперспективних формацій некімберлітового генезису й у межах Середньопридніпровського мегаблоку Українського щита - типового кратону архейського віку.

Наукова новизна. Установлені факти, що свідчать про реальність проявів потенційно алмазоносних формацій некімберлітового генезису в межах Середньопридніпровського мегаблоку. Під час діагностики флюїдно-есплозивних утворень району, що вивчався, була виділена низка структурних особливостей, які спостерігалися виключно у флюїдолітах. Флюїдно-експлозивні утворення також містять аномальні концентрації благородних металів.

Практична значимість. Результати досліджень дозволяють прогнозувати можливість відкриття нетрадиційних алмазоперспективних формацій некімберлітового генезису в межах Середньопридніпровського мегаблоку Українського щита.

Ключові слова: рудні формації, флюїдно-експлозивні утворення, пірокластичні кімберліти, метаконгломератобрекчіi, алмази, генезис

\section{Некимберлитовые источники алмазоносности и перспективы их обнаружения в пределах Украинского щита}

\section{М. В. Рузина, О. А. Терешкова, Н. В. Билан, И. В. Жильцова}

Государственное высшее учебное заведение „Национальный горный университет“, г. Днепр, Украина, e-mail: ruzinamari@gmail.com

Цель. Обоснование перспектив потенциально алмазоносных формаций некимберлитового гене- 
зиса и совершенствование критериев прогнозирования месторождений алмаза в пределах Украинского щита.

Методика. Комплексное изучение особенностей строения, вещественно-индикационных признаков и закономерностей распределения потенциально алмазоносных формаций некимберлитового генезиса. При изучении петрографических особенностей и состава рудной минерализации проводилось изучение шлифов и аншлифов с использованием рудно-поляризационного микроскопа Альтами ПОЛАР Р-312. Для обоснования вещественного состава алмазоперспективных пород проведена интерпретация результатов рентгеноструктурного, термического, микрозондового анализов.

Результаты. Флюидно-эксплозивные образования, выявленные в пределах Ингульского мегаблока Украинского щита, являются алмазоносносными формациями. Флюидно-эксплозивные образования Белозерской зеленокаменной структуры Среднеприднепровского мегаблока Украинского щита во многом аналогичны вышеуказанным образованиям, а также алмазоносным филлитам района Диамантина (Бразилия) и алмазоносным вишеритам Урала. Это, по аналогии с рядом рудных провинций мира, позволяет прогнозировать возможность открытия нетрадиционных алмазоперспек- тивных формаций некимберлитового генезиса и в пределах Среднеприднепровского мегаблока Украинского щита - типичного кратона архейского возраста.

Научная новизна. Установлены факты, свидетельствующие о реальности проявлений потенциально алмазоносных формаций некимберлитового генезиса в пределах Среднеприднепровского мегаблока. При диагностике флюидно-эксплозивных образований изучаемого района выделен ряд структурных особенностей, наблюдаемых исключительно во флюидолитах. Флюидно-эксплозивные образования также содержат аномальные концентрации благородных металлов.

Практическая значимость. Результаты исследований позволяют прогнозировать возможность открытия нетрадиционных алмазоперспективных формаций некимберлитового генезиса в пределах Среднеприднепровского мегаблока Украинского щита.

Ключевые слова: рудные формации, флюидно-эксплозивные образования, пирокластические кимберлиты, метаконгломератобрекчии, алмазы, генезис

Рекомендовано до публікації докт. геол. наук В.Ф.Приходченком. Дата надходження рукопису 28.07.17. 